
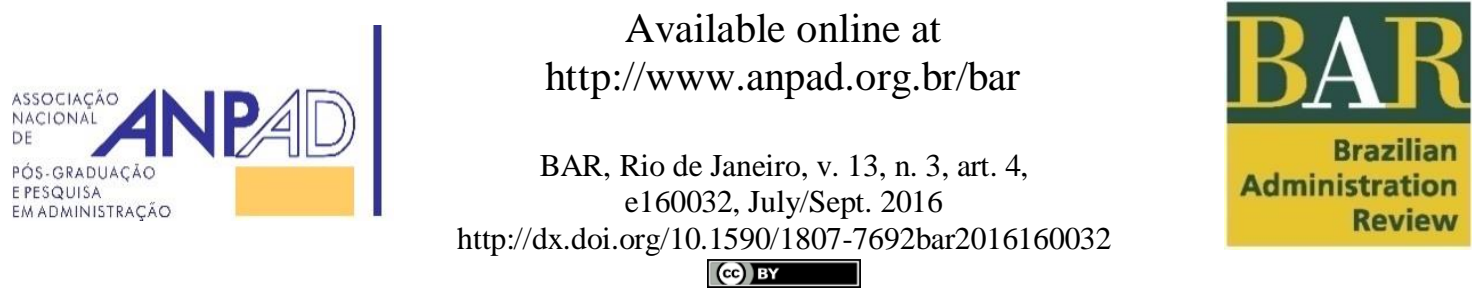

\title{
Economic Incentives or Communication: How Different Are their Effects on Trust
}

Tatiana Iwai ${ }^{1}$ Paulo Furquim de Azevedo ${ }^{1}$ Insper Instituto de Ensino e Pesquisa ${ }^{1}$ 2016; published online 19 October 2016. 


\begin{abstract}
This study investigates the effects of economic incentives and communication on the cognitive and behavioral responses after an alleged trust violation. We argue that these responses depend on the type of solution used to foster cooperation between agents. On the cognitive level, we compare the effects that structural (economic incentives) and motivational (communication) solutions exert on trusting beliefs and trusting intentions after an adverse event. On the behavioral level, we compare these effects on the willingness to bear risk. Our experiment shows that, after a negative event, relationships wherein communication is used to foster cooperation are associated to greater external causal attribution, greater perceived benevolence/integrity, and greater willingness to reconcile and to accept risks related to other's behavior. These findings suggest that relationships based on motivational solutions are more resilient to negative events than ones based on structural solutions.
\end{abstract}

Key words: trust violation; communication; economic incentives; trustworthiness; trust. 


\section{Introduction}

Trust plays a fundamental role in all human interactions, including economic transactions (Fehr, 2009). It is associated to several benefits, such as positive effects on cognitive, attitudinal and behavioral processes, generating superior collective performance results in organizations (Dirks \& Ferrin, 2001). These various positive consequences notwithstanding, researchers have been examining numerous episodes where trust may be violated. Lying, broken promises, breaches of contracts and rules change after the fact are some cases of trust violations reported (Bies \& Tripp, 1996). This paper advances the understanding of this subject by investigating the effects of economic incentives and face-to-face communication on the cognitive and behavioral responses to an alleged trust violation.

When a trust violation occurs, it disconfirms positive expectations regarding another's conduct and, hence, it may change the perception of the offended party about the reliability of the relationship (Tomlinson, Dineen, \& Lewicki, 2004). Reactions to violations of trust can be divergent, ranging from people choosing to get even, while others prefer to give another chance and reconcile. There is a growing recognition of the importance of understanding why people react differently to such violations in order to better manage their future exchange relationships (Dirks, Lewicki, \& Zaheer, 2009). Past research has been focused primarily on verbal allegations or other offender tactics that might repair trust once it has been lost after a broken promise (Kim, Cooper, Dirks, \& Ferrin, 2013; Kim, Dirks, Cooper, \& Ferrin, 2006; Kim, Ferrin, Cooper, \& Dirks, 2004; Lount, Zhong, Sivanathan, \& Murnighan, 2008; Tomlinson et al., 2004). Yet little attention has been paid to explore antecedents and characteristics of the relationship that might influence how a violation is perceived and ultimately managed.

How parties construe an alleged trust violation may depend on the nature of past relationship, once parties take into account the relationship as a whole when they evaluate a negative outcome. In other words, the history of a relationship matters. Although the literature addressed the role of prior violations and quality of past relationship (Elangovan, Rizzi, \& Szabo, 2007; Tomlinson et al., 2004), no prior work has explored the effects of the mechanism to foster cooperation on the interpretation of an alleged trust violation.

A history of cooperation may be based in two widely studied experimental settings: structural and motivational solutions (Agarwal, Croson, \& Mahoney, 2010; Boone, Declerck, \& Kiyonari, 2010; Kollock, 1998; Van Lange, Balliet, Parks, \& Van Vugt, 2013; Zeng \& Chen, 2003). While the first one focuses on economic incentives for cooperation; the second one focuses on interpersonal processes (e.g., communication). Therefore, both may lead to cooperative behavior and are valid mechanisms of governance, but each one works in a diverse way to achieve cooperation (Falk \& Kosfeld, 2006; Malhotra \& Murnighan, 2002).

Although the literature was quite prolific in both veins, there is still a lack of understanding about its effects in situations of trust violation. Does the type of mechanism foster cooperation affect the attribution process of a negative episode? And to what extent it can influence the risk taken in subsequent interactions with the same partner?

In this paper we investigate how these two ideal types of relationship, based on economic incentives or based on interpersonal processes, might influence how parties make attributions about the causes of a negative outcome (Heider, 1958; Weiner, 1986) and how this interpretation of causality might affect trusting beliefs and trusting intentions about the partner and on the victim willingness to bear risk after an alleged trust violation. We designed and implemented an experiment in which we manipulate different relational histories in order to test how parties react to an alleged trust violation, i.e. a negative shock that they cannot observe if it was caused by nature or by opportunistic behavior of the counterpart. As expected, results show that relationships based on interpersonal process tend to be more resilient to external shocks than relationships in which cooperation was based on economic incentives. 
The contributions of this paper are threefold. First, we examine the effects of prior relationship based on economics incentives or interpersonal processes - on how parties interpret and react to a trust violation. Second, we show that relationships based on interpersonal relations (e.g. face-to-face communication) are more resilient to external shocks. Finally, we add to a growing body of work that apply experimental methods to address strategy related inquiries in the contracting and interfirm exchange literatures (Agarwal et al., 2010; Harmon, Kim, \& Mayer, 2015; Lazzarini, Miller, \& Zenger, 2004).

This paper is organized as follows. First section summarizes the literature on economic incentives and communication as mechanisms to support cooperation, as well the concept of perceived trustworthiness, from which we derive the hypotheses that guide the experiment and discussion. Second section presents the experimental design and how variables are measured and the hypotheses are tested. In the third section, we present and discuss the results. Finally, we discuss some managerial implications, as well as the limitations of this study and offer suggestions for future research.

\section{Theory and Hypotheses}

\section{Economic incentives and communication as mechanisms to support cooperation}

Across the years, researchers have studied possible solutions to improve cooperation in situations where individual and collective interests are in conflict. In this discussion, a distinction between two broad categories of solutions is often made: structural and motivational solutions (Kollock, 1998; Komorita \& Parks, 1994; Messick \& Brewer, 1983; Van Lange, Joireman, Craig, \& Djik, 2013).

Broadly speaking, structural solutions change the economic incentives so that the dilemma can be modified or entirely eliminated. They involve any tangible changes in the parameters of the game structure that enhance the partner's payoff for cooperative behavior (Zeng \& Chen, 2003). Changes in the payoff structure, reduction of group size, changes in the allocation rules, sanction systems and introduction of provision points are some examples of structural solutions (Davis \& Holt, 1993; Ledyard, 1995). All of them have in common the fact that cooperative behavior has an instrumental value in the sense that it results of an enlargement of the payoff for cooperation. Therefore, when explicit incentives (tangible rewards for cooperation or tangible punishment for opportunism) are present, conflict between personal and collective interest decreases. Indeed, Balliet, Mulder and Van Lange (2011), in a recent meta-analysis, show that sanctions and rewards exhibit substantial positive effect on cooperation.

The social dilemma literature offered two main explanations for this effect. One explanation is that rewards and sanction systems reduce the attractiveness of opportunism, due to penalties provided to non-cooperative behavior. Another explanation is the indirect effect on expectations regarding other's choices, since the existence of penalties for defection assures that others will not exploit cooperators (Balliet \& Van Lange, 2013; Barclay \& Kiyonari, 2014; Tenbrunsel \& Messick, 1999).

In sum, cooperation results from a calculation which weighs the costs and benefits of a given action orientation, choosing the course of action which produces the higher gains (Zeng \& Chen, 2003). According to this logic, when the agent acts in a cooperative fashion, he assumes that current gains resulting from opportunism will be outweighed by the loss of future gains.

However, some authors argue that economic incentives can create a second order dilemma, i.e. the problem of the compliance with a sanction system (Nosenzo \& Sefton, 2013; Van Lange, Joireman et al., 2013). While a surveillance or sanction system may be good for the collective, they are costly and individuals may not be willing to contribute with resources in order to maintain them (Fehr \& Gatcher, 2002). In comparison, motivational solutions are more cost-effective mechanisms to improve cooperation (Van Lange, Joireman et al., 2013; Zeng \& Chen, 2003). They rely on more intangible ways 
to change individual's perception of the social environment. Social value orientation (Balliet, Parks, \& Joireman, 2009; Bogaert, Boone, \& Declerck, 2008), face-to-face communication (Balliet, 2010; Sally, 1995), group identity (Jackson, 2011; Kollock, 1998; Meleady, Hopthrow, \& Crisp, 2013; Orbell, Van de Kragt, \& Dawes, 1988), long-term goals among partners (Axelrod, 1984; Weber \& Murnighan, 2008) are some examples of motivational solutions. Among them, face-to-face communication, in which individuals have the opportunity to discuss the dilemma they are facing and make pledges or communicate intended choices, is considered the most robust and effective mechanism of the motivational solutions. For instance, Sally (1995), in a meta-analysis review, showed that this form of communication increases cooperation by $40 \%$.

Although the positive effects of communication on rates of cooperation are well documented, what is less discussed relates to the underlying mechanisms that account for such cooperative behavior. Some authors (Cohen, Wildschut, \& Insko, 2010; Messick \& Brewer, 1993; Tazelaar, Van Lange, \& Ouwerkerk, 2004; Weber, Kopelman, \& Messick, 2004; Zeng \& Chen, 2003) offer some possible explanations: (a) communication offers an opportunity for moral suasion among group members, stressing what is right and appropriate to do; (b) when discussing the common problem they face, individuals may create a sense of group identity that can foster group norms and reduce the psychological distance between private and collective interest; (c) it also provide valuable information regarding other's choices, facilitating conformity pressures in favor of collective choices; and (d) it offers the possibility for individuals to make promises about a particular course of action and in turn alleviating the perceived risk of unilateral cooperation and coping with noise that harms impressions of benign intent. Although the first explanations are more associated to group dilemmas (group identity and moral suasion), the latter effects also apply to dilemmas involving two persons.

In sum, by noting these different solutions to social dilemmas, we intend to argue that cooperation can be grounded on different social basis and they might influence differently how individuals perceive and respond to possible adverse events that may occur in a relationship and, in turn, might change the perceived trustworthiness of the partner.

Therefore, differently from previous studies that focused on which solutions is more effective to foster cooperation or how they interact, as substitutes or complements (Lazzarini et al., 2004; Mellewigt, Madhok, \& Weibel, 2007; Woolthuis, Hillebrand, \& Nooteboom, 2005), the present work aims to investigate how these alternative mechanisms of governance might influence the attribution process about an alleged trust violation and how these interpretation might affect trusting beliefs, trustworthiness and the willingness to bear risk in future interactions.

\section{Perceived trustworthiness and causal attribution}

Although there is not a widely accepted scholarly definition of trust, positive expectations and willingness to be vulnerable are elements that are commonly observed in many definitions (Mayer, Davis, \& Schoorman, 1995). Rousseau, Sitkin, Burt, and Camerer (1998, p. 395), for example, define trust as "a psychological state comprising the intention to accept vulnerability based upon positive expectations of the intentions or behavior of the other".

Several studies have been focusing on conditions that lead to trust. Among them, some authors argue that the level of trust one party has for another depends on some attributes of the trustee. These factors lead to a greater or lesser perception of trustworthiness of the other. According to Mayer, Davis and Schoorman (1995), three factors help to explain the amount of trust for another party: ability, benevolence and integrity. Ability reflects the perceived technical competence on a specific domain that allows one to perform significant tasks on that area. Benevolence is related to the perception of goodwill of the trustee, who is concerned to the trustor's well-being. Regarding integrity, it reflects the perception that the trustee is aligned with a set of principles and values that the trustor understands as acceptable.

Hence, in general, variations in perceptions of ability, benevolence and integrity explain some part of the initial variation of trust one party has for another. Such initial level of trust, however, evolves over time as the parties interact. Consequently, trust has a dynamic nature and is dependent of the history 
of the relationship. As parties interact, initial expectations are adjusted, as a response to cumulative experiences they share with each other, which weakens or confirms initial judgments. Thus, cumulative interaction between parties provides relevant information to assess other's dispositions and intentions and, as a result, it helps to predict counterpart's behavior (Kramer, 1999; Kramer \& Lewicki, 2010).

When a negative incident occurs and parties cannot directly observe its source, it is expected that parties engaged in a relationship try to assess the possible causes of the unexpected event (Elangovan $e t$ al., 2007; Kim et al., 2013; Lewicki \& Bunker, 1996; Weiner, 1986). This process of causal attribution relies on three primary dimensions: locus of causality, controllability and stability (Weiner, 1986, 2012). The first dimension relates to the source of the outcome. Was it generated internally (by the trustee) or externally (by exogenous factors)? The second dimension refers to the degree of control an individual had over the outcomes or if the partner could have avoided or mitigate the undesirable outcome. Finally, stability refers to the degree to which the cause can be considered permanent or temporary. It relates to the likelihood of future occurrence of the episode. The result of this causal assessment has an effect on the counterpart's trustworthiness and, hence, on trust (Tomlinson \& Mryer, 2009).

\section{Solutions for cooperation and cognitive response to trust violations}

As noted earlier, in a relationship wherein cooperation is based on economic incentives, positive expectations regarding other's behavior emerge due to the existence of explicit rewards that foster cooperation (Lewicki \& Bunker, 1996) and, as some authors argue (Falk \& Kosfeld, 2006; Malhotra \& Murnighan, 2002), it may lead to a substitution effect in which the use of economic incentives might weaken the positive effects of interpersonal processes. In situations where there are explicit incentives for cooperation and clear sanctions for opportunism, cooperative action is usually ascribed to the situational factors (economic incentives) and not to the intrinsic motivation to cooperate (Frey \& Jegen, 2001).

Thus, this sort of incentive for cooperation just lessens vulnerability or risk, but does not enhance perceived trustworthiness of the other, because when someone has no other rational option but to cooperate, due to the presence of incentives and punishments/fines, there is no reason to assure that person is intrinsically trustworthy.

As a result, negative outcomes are likely to be perceived as a consequence of greed and malfeasance of the other. Consequently, in an attribution analysis, the negative outcome may be seen as having an internal locus and as something that could be avoided by the counterpart. The above discussion supports the following hypothesis.

Hypothesis 1: In relationships wherein cooperation is based on economic incentives, the causal attribution of a negative event is more internal than when cooperation is based on communication.

Such attribution, in turn, may damage perceived benevolence and integrity, since the offended party will ponder that the other defected. Moreover, stability will probably be disturbed too, because malevolence and lack of commitment to acceptable principles are considered more stable traits (Tomlinson \& Mryer, 2009).

Consistent with this assertion, prior studies (Elangovan et al., 2007; Elangovan \& Shapiro, 1998; Harmon et al., 2015; Morrison \& Robinson, 1997) found that erosion of trust is stronger, when the trustor perceives that the undesirable episode stemmed from a trustee's conscious decision of refusing to meet trustor's expectations. When the trustor feels that the counterpart at least tries to do the right thing, but could not meet trustor's expectations, some credit can still be given to the offender and the fault may be seen as temporary and less likely to be repeated in the future. When this is not the case, however, perceived trustworthiness will decrease due to the lessening in perceived benevolence, integrity and stability. Moreover, the willingness to reconcile the relationship is smaller.

However, cooperation is achieved not only through economic mechanisms (tangible rewards and punishments), but also by means of sociological mechanisms (social norms) (Poppo \& Zenger, 2002). 
When the latter is nurtured by communication among parties, social norms of mutual obligation may create a perception of benevolence and a belief in good faith and moral character of the other. Thus, in the occurrence of a negative event, although the locus of causality may still be internal, perception of controllability over the outcome tends to be alleviated. In addition, the negative event tends to be considered as transitory and, as such, less likely to be repeated in future interactions. Consequently, under previous communication, perceived benevolence and integrity are more resilient to negative shocks. This discussion supports the following hypotheses:

Hypothesis 2a: In case of a negative event, relationships wherein cooperation is based on communication are associated with a greater perceived benevolence between parties than when cooperation is based on economic incentives.

Hypothesis 2b: In case of a negative event, relationships wherein cooperation is based on communication are associated with a greater perceived integrity between parties than when cooperation is based on economic incentives.

Consistent with McKnight, Cummings and Chervany (1998), we differentiate between trusting beliefs and trusting intentions, where the first one refers to the beliefs about one's perceived integrity or perceived benevolence, while the second one refers to a willingness to make oneself vulnerable to another in the presence of risk.

Past research on the effects of verbal allegation on trust has already made this differentiation between trusting beliefs and trusting intentions, due to the recognition that trust is a multifaceted and complex construct and, as such, trust repair efforts need to focus on activities directed at making trusting beliefs, as well as trusting intentions, more positive (Kim et al., 2006; Kim et al., 2004; Lount et al., 2008; Tomlinson et al., 2004).

In the same vein, a history of cooperation, based on economic incentives or face-to-face communication, might influence not only beliefs about another's integrity or benevolence, but also one's willingness to depend on others (trusting intentions). Therefore, in the occurrence of a negative event, in order to rebuild trust that may have been damaged, economic incentives and communication will be associated not only to different levels of trusting beliefs, but also to different trusting intentions. Thus:

Hypothesis 3: In case of a negative event, relationships wherein cooperation is based on communication are associated with a greater willingness to reconcile than when cooperation is based on economic incentives.

\section{Solutions for cooperation and behavioral response to trust violations}

A great obstacle to build trust relates to the initial lack of trust between parties. As such, initial actions of each party display considerable effect on the subsequent development of the relationship (Cook et al., 2005; Lount et al., 2008; Pillutla, Malhotra, \& Murnighan, 2003). These preliminary shared experiences will provide useful information to update the initial perceived trustworthiness of the other and adjust behavior in future interactions. Likewise, in a process of repairing trust, one may argue that the first decisions soon after the negative event display similarities with the decisions made in the beginning of the relationship and may play an important role in the future of the relationship, since the first actions may signal how well the violation was overcome and if the level of trust remained unaltered compared to those initially set.

After an alleged trust violation, however, taking risks may be more problematic, since new effort should be employed in order to rebuild trust that may have been eroded. The process of repairing trust can be even harder than building trust initially, since a violation can lead trust to drop to a level below those set initially. As a consequence, the level of effort required to predispose a subject to take a risk position again gets a much larger magnitude (Elangovan et al., 2007; Kim et al., 2006; Kim et al., 2004). However, taking relatively small risks may signal hostile act, lack of trust or raise questions about the motives for the other not having trusted more. This, as a result, reduce social reciprocity, which is 
associated with the "non-strategic conditional willingness to reward kind acts (positive reciprocity) and to punish unkind ones (negative reciprocity), even if this is costly for the reciprocating subject" (Falk, Gatcher, \& Kovacs, 1999, p. 254). In other words, social reciprocity relates to an intrinsic motivation to respond to the behavior of the other. As such, taking small risks might impair positive social reciprocity, lessening cooperation levels between parties (Fehr \& Schmidt, 2007; Frey \& Jegen, 2001). As Falk and Kosfeld (2006, p. 1629) state: "trusting a bit is likely to be interpreted as not trusting at all".

As economic incentives create a perception of cooperation based on situational attributions, while communication ascribe cooperation to the goodwill of the other (dispositional attribution), it can be expected that, after a negative episode, assuming a risk position is more likely when cooperation is achieved through communication than when economic incentives are in place. Thus:

Hypothesis 4: In relationships wherein cooperation is based on communication, the party affected by a negative event takes a higher risk position than when cooperation is based on economic incentives.

\section{Method}

To test the hypotheses presented in the previous section, we designed an experiment, in a controlled environment, that allowed for the treatment of two mechanisms that induce cooperation: economic incentives and communication. We could then explore how these two different types of relationships - based on communication or based on economic incentives - were affected by a negative event whose cause was not observable by one of the parties.

\section{Design and procedure}

The experiment consisted of two games. In the first game, pairs of participants played a public good provision game for 11 periods. To each participant, an endowment of 20 tokens was given at the beginning of each period. Then, an individual decision should be made between invest any amount of the endowment to one of two accounts: a personal account $(\mathrm{P})$ or a group account $(\mathrm{G})$. The investment in the $\mathrm{P}$ account belonged totally to the individual; the investment in the $\mathrm{G}$ account received a certain amount of interest (it was multiplied by an efficiency factor of 1.6) and shared equally between the subjects of the same pair. As in any public good provision game, there was a feature of non-exclusion. In others words, the earnings from the $\mathrm{G}$ account were shared equally, no matter how much each agent invested at the provision of the public good. So each member's payoff was given by the sum of the investment made in the P account and a share in the G account. Each member's utility $i$ was calculated by the following formula:

$$
U_{i}=P_{i}+\frac{\left(G_{i}+G_{j}\right) r}{2}
$$

Where $P_{i}$ is the amount invested in the personal account $\mathrm{P}$ by member $i ; G_{j}$ is the amount invested in the $\mathrm{G}$ account by each member of the pair; $r$ is the efficiency factor on the contributions in the group account $\mathrm{G}$ (in our experiment, $r=1.6$ ). In this game, the dominant strategy is to allocate every token in the $\mathrm{P}$ account, though investing in the $\mathrm{G}$ account is the social optimum (Pareto efficiency).

Using the public good provision game as a baseline, we implemented two different conditions to create a specific history of relationship - based on communication or on economic incentives (bonus). Pairs were assigned randomly to each type of condition.

For the communication condition, subjects first read instructions about the game in the computer screen in their private cabins. Then, before the first period of the PGG game, subjects of the same pair 
were allowed to communicate face-to face for ten minutes in a separate location, where others participants could not listen what was being discussed. Participants were free to discuss any topic they wished, including strategies to cope with the dilemma they were facing. When the discussion time was over, subjects went back to their private cabins, where any other form of communication was strictly prohibited.

This mechanism did not alter payoff's function. As we argued before, face-to-face communication between parties is able to mitigate the problem of opportunism in social dilemmas due to social pressure, moral persuasion, identification and interests sharing (Bottom, Gibson, Daniels, \& Murnighan, 2002; Messick \& Brewer, 1983; Ostrom, Walker, \& Gardner, 1992; Shapiro, 1991).

The economic incentives condition worked as follow: at each period, if the joint amount contributed to $\mathrm{G}$ account was equal or greater than $G^{*}=32$ tokens, each subject of the pair received a 10 tokens bonus. If contributions in the $\mathrm{G}$ account did not reach $G^{*}$, no bonus was given. Consequently, in this condition, each member's utility $i$ is calculated by the following formula:

$$
U_{i}=\left\{\begin{array}{l}
P_{i}+\frac{\left(G_{i}+G_{j}\right) r}{2}+B \text { if } \frac{\left(G_{i}+G_{j}\right) r}{2} \geq G^{*} \\
P_{i}+\frac{\left(G_{i}+G_{j}\right) r}{2} \quad \text { if } \frac{\left(G_{i}+G_{j}\right) r}{2}<G^{*}
\end{array}\right.
$$

Where: $B$ is the bonus provided and $G^{*}$ is the minimum amount invested in the $\mathrm{G}$ account to receive the bonus. This mechanism worked as a variation of a provision point, but it did not require full endowment contribution of all players. As a result, each combination of subject's contributions, which reaches the provision point, is a Nash-equilibrium. To deal with this issue of multiple equilibria, subject's decisions were made sequentially (in both conditions to guarantee symmetry) in order to create a unique equilibrium in the game. At each period, one player was the first one to make the decision to contribute in the $\mathrm{G}$ account. This decision was informed to the other, who should then decide how much to contribute in the $\mathrm{G}$ account. In the next period, decisions order was reversed.

For all conditions, following each period, subjects were informed about their own contribution in the $\mathrm{G}$ account, as well as their partner contribution. Their own individual profit (accumulated and in the period) and their partner's profit (in the period) were also provided.

After eight periods, an unobservable shock was introduced to lower cooperation of one of the subjects in the pair. The purpose of this shock was to create uncertainty about the cooperative behavior of the other that could generate a perception of trust violation. Thus, at that point, the endowment of one of the players of each pair was reduced, while the other player's endowment remained unaltered. At the beginning of the experiment, subjects were informed that, after $8^{\text {th }}$ period, there was a chance that the endowment of one of the players could be reduced without notifying the other player of the pair for some randomly chosen pairs.

Accordingly, from $9^{\text {th }}$ to $11^{\text {th }}$ periods, player 1 's endowment was actually reduced in $40 \%$ (12 tokens) for all of the pairs, but this reduction was not observed by player 2 . This manipulation was necessary to create uncertainty about the real motives of player 1 strategy. Consequently, when player 1 contributed less in the $\mathrm{G}$ account in these periods, player 2 could not observe the reason for that: an endowment reduction, that she/he was aware that was possible, or an opportunistic behavior of player 1 to, free-ride on player 2's contribution in the G account.

After subjects played the PGG game, they filled out a questionnaire to assess perceived benevolence and integrity of the partner, as well as willingness to reconcile the relationship and causal attribution of the negative event.

Next, subjects played a one-shot investment game based on the experiment of Berg, Dickhaut and McCabe (1995). In this game, one player A chooses if he trusts or not in a player B, who then decides to honor or exploit trust. Then, initially each player receives an endowment of 10 tokens. While one of 
the players, say player B, pockets the initial endowment, the other player, say player A (trustor), must decide how much of his 10 tokens to send to player B (trustee). If player A decides send nothing, the game ends and each player pockets the endowment given by the experimenter. However if player A decides to send something, the amount sent is tripled. Next, player B, who received the amount tripled, must decide how much to return to player A.

From a rational perspective, player B's dominant strategy is to return nothing to player A. As player A anticipates player B's dominant strategy, the best strategy is to contribute nothing, which is the unique Subgame Nash Equilibrium. Consequently, any amount sent to player B leaves player A vulnerable, since player B can return none. Once this game is one-shot, there is no room for reputation building. This result is not collective efficient since any value sent by player A to player B enhances collective value.

Table 1

Type of Player by Game

\begin{tabular}{lll}
\hline & Public Good Game & Investment Game \\
\hline Player 1 & Alleged Offender & Trustee \\
Player 2 & Victim & Trustor \\
\hline
\end{tabular}

In the investment game, subjects remained with the same pairs of the public good game (PGG): one as trustor and the other as trustee. Trustor was performed by the player who had his endowment unchanged in the public good game (victim in the PGG, i.e. player 2). Trustee was performed by the player who had his endowment reduced by $40 \%$ in the public game (the alleged offender in the PGG, i.e. player 1), as shown in Table 1. As in the public good game, we contrast relationships wherein cooperation was induced by communication with those based on economic incentives. As stated by Hypothesis 4, we expect that the injured party takes a higher risk position in relationships of the first type.

To check if participants understood the structure of the games, right after the experimental instructions of each game (PGG and investment game), we applied quizzes with some questions to assess the subject's understanding of experimental parameters and payoffs. We checked the responses to make sure all participants understood the correct answers. For the communication condition, where participants could observe the identity of his/her pair, an additional check was included. In a questionnaire, we asked participants to state if they had a previous relationship with the person with whom they were paired in the experiment. None of them knew his/her pair before the experiment.

\section{Sample}

To test the hypotheses, we implemented an experiment with undergraduate business students at a Brazilian school. Participation was optional. Participants were $53 \%$ female, an average of 22 -years old and none of them had already participated in an experiment before. During four days, six experimental sessions were run at the lab with, on average, 20 participants per session. Each experimental session took, on average, 90 minutes. 116 students participated in this study and were broken into 58 random pairs upon arrival at the lab. Participants were rewarded with tokens that could be later exchanged by chocolate bars. The experiment was computerized using the software Z-Tree (Fischbacher, 2007). 


\section{Measures}

Hypotheses 1, 2 and 3 were tested by a questionnaire based on Weiner's causal attribution model (1986) and on Mayer et al. (1995) model of perceived trustworthiness. The questionnaire was translated to Portuguese and submitted to a validation test with students to evaluate understanding ${ }^{(1)}$.

Perceived Benevolence (H1): Four items, on a 5-point Likert scale, ranging from 1 = strongly disagree to $5=$ strongly agree, were used to assess perceptions of counterpart's benevolence, which is one of the elements of perceived trustworthiness (Mayer et al., 1995). This scale was adapted from Mayer and Davis (1999). Some of the resulting items were: "My partner is very concerned about my welfare" and "my partner really looks out for what is important to me". The Cronbach's $\propto$ for this scale was .85 .

Perceived Integrity (H1): five items were used to assess perceptions of counterpart's integrity. This scale was also based on the integrity scale used by Mayer and Davis (1999). Some of the resulting items were: "my partner has a strong sense of justice" and "sound principles seem to guide my partner's behavior". The Cronbach's $\propto$ for this scale was .88 .

Causal Attribution (H1): three items were used to assess to what extent the cause of the negative event can be attributed to the counterpart. These items were: "Is my partner responsible for not having contributed as much as I expected in the G account?", "Could my partner have done something to avoid or mitigate the negative event in the game?", "Do I expect that my partner behave opportunistically in future events?". The Cronbach's $\propto$ for these three items was .87 .

Willingness to Reconcile Relationship (H2): three items were used to assess subject's willingness to reconcile relationship after the negative event. It was a 7-point Likert scale, ranging from $1=$ highly unlikely to $7=$ highly likely. This scale was adapted from Tomlinson, Dineen and Lewicki (2004). These items were: "What is the likelihood that you will continue with your current partner, if you have the opportunity to move out for a new unknown partner?, "To what degree are you willing to reconcile the relationship with your partner?", "How difficult would it be to rebuild your relationship with your partner back to the point where it was at the beginning of the game?". The Cronbach's $\propto$ for these three items was .74.

Hypothesis 4 was tested by the decisions made in the investment game. This game was designed to assess trustworthiness by means of objective actions rather than statements. As the defensive strategy for the trustor is to keep all tokens for himself/herself, the amount that he/she sends to the trustee is a measure of risk position. The higher this amount, the more the trustor's payoff depends on the trustee. For this reason, risk taken (H4) was measured by trustor decision of how much to send (from 1 to 10 tokens) to the counterpart after a negative event. We expect that trustors will send a higher amount if their past relationship with trustees is based on face-to-face communication rather than on economic incentives, as stated by Hypothesis 4 .

\section{Results}

The PGG game had two main goals: one relates to the creation of a history of cooperation based on structural and motivational solutions. Therefore, two conditions (bonus and communication) were manipulated for this purpose. Secondly, in the three last rounds of the PGG game, an adverse shock was introduced in order to disturb the ongoing cooperation and cause a possible perception of trust violation.

In the first eight rounds of the game, on average, players contributed $78.77 \%$ of their endowment in the $\mathrm{G}$ account (15.75 tokens). No difference was observed between bonus and communication conditions $\left(M_{\text {bonus1-8 }}=78.88 \%\right.$ vs. $M_{\text {com1- } 8}=78.66 \% ; M_{\text {bonus1-8 }}=15.78$ vs. $\left.M_{\text {coml- } 8}=15.73\right), F(1,114)=$ 
$0.01, n s$ ), showing that both mechanisms enhanced cooperation levels in a similar fashion, as shown in Figure 1.

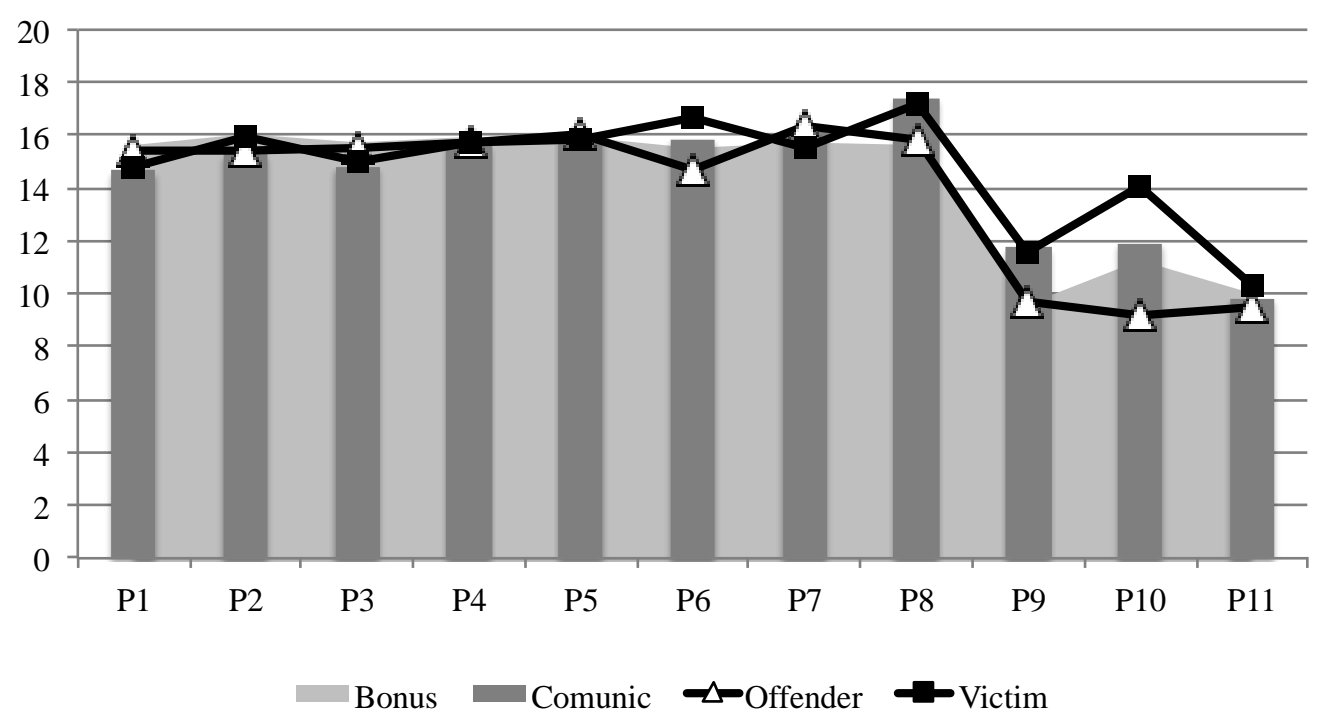

Figure 1. Average Contribution in G Account per Player across Periods in the PGG

After the $8^{\text {th }}$ round, when the offender's endowment (player 1) was reduced, contributions dropped similarly in both conditions $\left(M_{\text {bonus9-11 }}=65.97 \%\right.$ vs. $M_{\text {com9-11 }}=73.07 \% ; M_{\text {bonus9-11 }}=10.24$ vs . $\left.M_{\text {com9-11 }}=11.25\right), F(1,114)=2.047, n s$, and $F(1,114)=1.563, n s$, respectively. However, there was a difference in contributions by type of player. Offenders' contributions (player 1) did not change significantly as a percentage of their endowment (that was now lower due to the reduction of $40 \%$ ) $\left(M_{\text {Offender1-8 }}=78.31 \%\right.$ vs. $\left.M_{\text {Offender } 9-11}=79.02 \%, t(56)=-.002, n s\right)$. The alleged victims' contributions (player 2) decreased in relative terms $\left(M_{\text {Victim-8 }}=79.23 \%\right.$ vs. $M_{\text {Victim9-11 }}=60.02 \%, t(56)=5.61, p<$ .001 ). As shown in Figure 1, the drop in offenders' contributions in absolute terms (but not in relative terms) was followed by a reduction in victims' contributions both in absolute and relative terms (since their endowment remained the same).

Although no significant difference in contributions was observed between conditions in the last three rounds of the game, victims judged differently the cause of the negative outcome. Causal attribution was more internal in the bonus condition in comparison to the communication condition, when victims attributed more culpability and responsibility to the counterpart, as shown in Table 2 (means difference is statistically significant, with $F(1,56)=6.195, p=.016$ ). This result provides support for hypothesis 1 .

Moreover, comparing trusting beliefs measures, perceptions of Benevolence $(F(1,56)=6.712, p$ $=.012)$ and Integrity $(F(1,56)=4.664, p=.035)$ were also lower for the bonus condition, as shown in Table 2 . These results provide support to hypotheses $2 \mathrm{a}$ and $2 \mathrm{~b}$. As for trusting intentions, victims were less willing to reconcile under the bonus condition $(F(1,56)=5.917, p=.018)$, supporting Hypothesis 3 . 
Table 2

Means and Standard Deviations of Perception of Victims by Condition

\begin{tabular}{lllllll}
\hline & \multicolumn{2}{l}{ Bonus (economic incentives) } & & & \multicolumn{2}{l}{ Communication } \\
\cline { 2 - 3 } \cline { 6 - 7 } & $\mathrm{M}$ & $\mathrm{SD}$ & & $\mathrm{M}$ & $\mathrm{SD}$ \\
\hline Benevolence & 2.70 & 0.76 & & 3.27 & 0.91 \\
Integrity & 2.82 & 0.93 & & 3.36 & 0.97 \\
Causal Attribution & 3.31 & 0.95 & & 2.63 & 1.12 \\
Willingness to Reconcile & 4.59 & 1.31 & & 5.45 & 1.39 \\
\hline
\end{tabular}

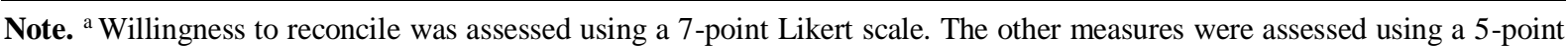
Likert scale.

Results from the investment game show that, in the communication condition, the average of tokens sent by the trustor (player 2) was 8.59 and the average percentage returned by the trustee was $45 \%$. Both trustee and trustor received an average payoff significantly higher than the Subgame Nash Equilibrium payoff (10 given the sending nothing strategy): 13.62 for trustor $(p=.002)$ and 23.55 for trustee $(p<.001)$. In the bonus condition, the average of tokens sent was equal to 6.62 and the average percentage returned equal to $38 \%$. The average gain of the trustor equal to 11.41 , that is not significantly larger than $10(p=.136)$. However, the average gain of the trustee equal to 21.83 and the average joint payoff equal to 33.24, both significantly higher than $10(p<.001)$ and $20(p<.001)$, respectively.

Consequently, in both conditions, the trusting behavior produced benefits to the trustee. Compared to the strategy of sending nothing, however, trustor was best served only in the communication condition. Moreover, in both conditions, the trustee has absorbed most of the value created by the risk taken by the trustor.

The type of relationship largely affected the amount sent by the trustor. In the communication condition, the trustor sent a significantly larger amount than in the bonus condition ( $M_{\text {bonus }}=6.62 \mathrm{vs}$. $M_{\text {com }}=8.59$, Mann-Whitney, $p=.002$ ). Accordingly, the joint payoff was greater in relationships wherein cooperation was based on communication rather than on economic incentives.

In both conditions, trustor's decisions have concentrated largely on the focal points 5 and 10 , as shown in Figure 2. In the communication condition, these two focal points accounted for $89 \%$ of the total choices made, though decision to send 10 tokens (maximum risk position) was more frequent (72\% of total choices). In the bonus condition, decisions to send 5 and 10 tokens were observed in $66 \%$ of the pairs; with 5 tokens as the modal choice, with $38 \%$ of the total.

When grouping trustor's decision in two categories: (a) lower amounts sent ( 0 to 5 tokens) and (b) higher amounts sent (6 to 10), a Chi-Square test confirms that the latter was more frequent in the communication condition than in the bonus condition $\left(M_{\text {bonus }}=48 \%\right.$ vs. $\left.M_{\text {com }}=79 \%\right), \chi^{2}(1,58)=6.05$, $p=.014)$. 


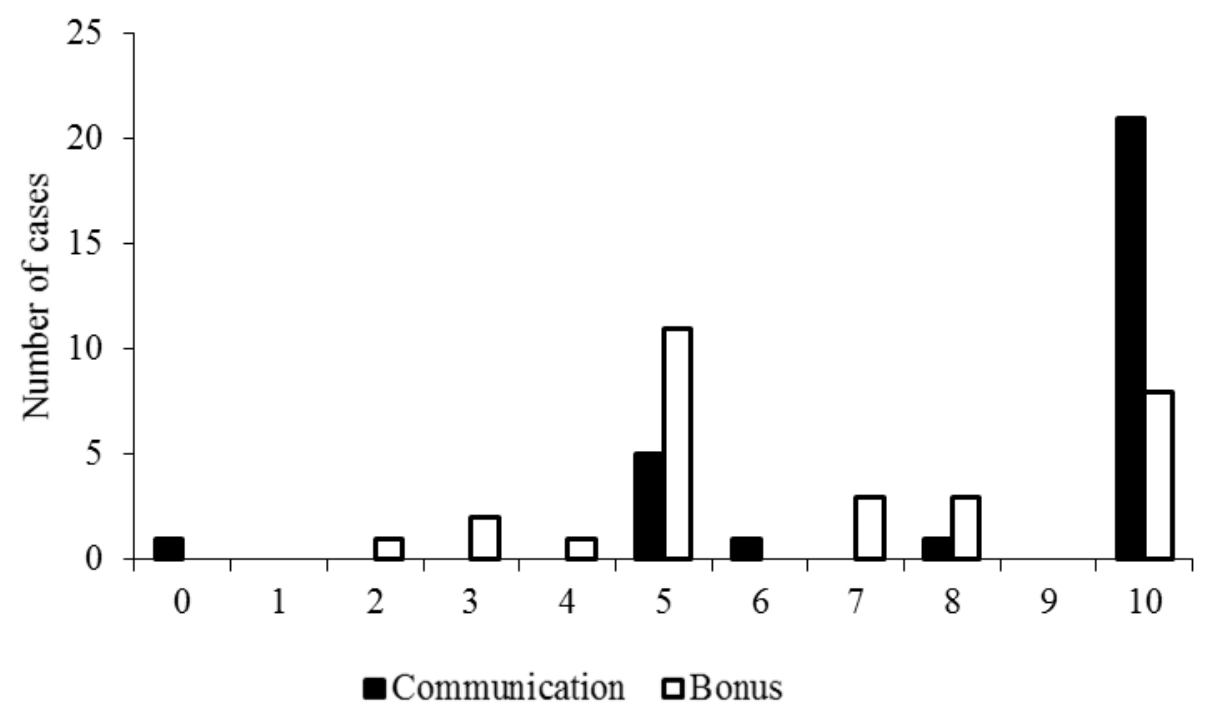

Figure 2. Distribution of Amount Sent by the Trustor per condition in the Investment Game

Such differences in risk taken in each condition are consistent with the perceptions of trust violation discussed previously. A Spearman's rank correlation shows significant correlation between risk position and: benevolence $(r=.297, p=.012)$, integrity $(r=.291, p=.013)$ and causal attribution $(r=-.336, p=.005)$. Once subjects in the bonus condition showed lower trusting beliefs and intentions than subjects in the communication condition, it is expected that the former display lower willingness to take risks in the investment game than the latter. Moreover, using the already mentioned categories of trustor's decision ( 0 to 5 tokens sent and 6 to 10 tokens sent), it is possible to observe differences in perceptions of trusting intentions $\left(M_{0-5}=2.73\right.$ vs. $M_{6-10}=3.21$, Mann-Whitney, $\left.p=.026\right)$ and causal attribution $\left(M_{0-5}=3.40\right.$ vs. $M_{6-10}=2.73$, Mann-Whitney, $\left.p=.022\right)$. These results support Hypothesis 4 .

There was no direct effect of economic incentives and communication on the trustee decision, which was the party that was not subject to uncertainty in the PGG game. Percentages returned by the trustee $\left(M_{\text {bonus }}=38.97 \%\right.$ vs. $\left.M_{\text {com }}=45.09 \%\right)$ were not significantly different in communication and bonus conditions (Mann-Whitney, $p=.148$ ). However, there was evidence that trustor and trustee decisions are related. A Spearman correlation shows significant correlation between trustor and trustee decision $(r=.324, p=.007)$. Similarly to the score found by Berg et al. (1995), this result indicates that the decision to return tokens by the trustee is somehow influenced by the previous decision to trust by the counterpart. 


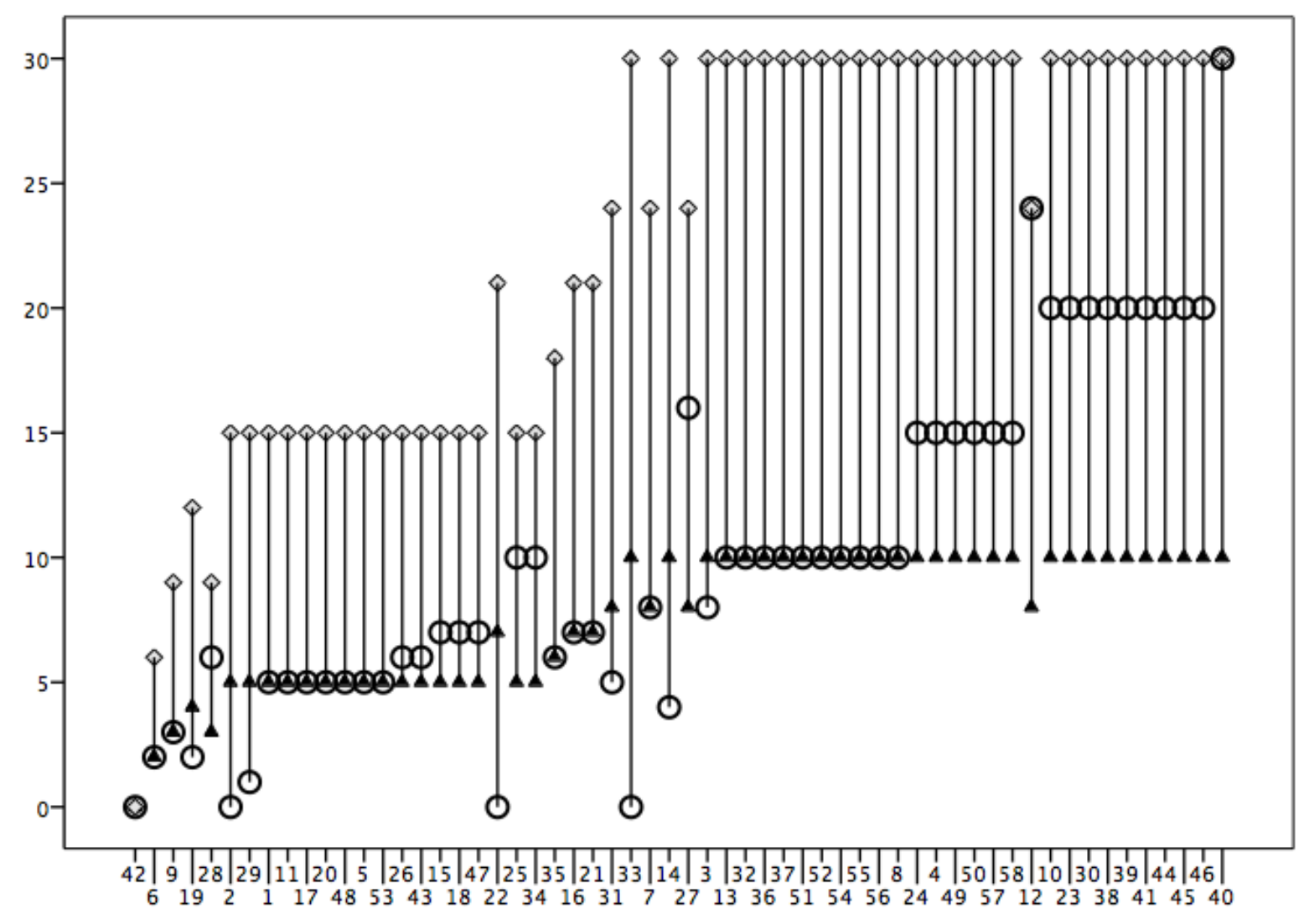

$\Delta$ Trustor Decision $\quad \diamond$ Amount $3 \mathbf{O X} \quad$ OTrustee Decision

Figure 3. Trustor and Trustee Decisions in the Investment Game

Figure 3 displays the decisions of each pair of subjects in the investment game and shows that the most frequent return strategy is the give back - where the trustee returns exactly the amount sent by the trustor, and appropriates the entire surplus generated by the joint investment - (which accounted for $43 \%$ of the choices). Also, it is noteworthy that trustees' strategies are more generous than the give back strategy, when the trustor takes maximum risk (i.e. to send 10 tokens). As displayed in Figure 3, some players have decided to return 20 tokens (out of a total of 40 tokens), aiming to equalize outcomes with the counterpart.

\section{Discussion}

The findings of this study help to clarify the effects of economic incentives and communication on the cognitive and behavioral responses after an alleged violation. The analysis provides evidence that these two mechanisms to foster cooperation are associated to different patterns of response, such as perception of trustworthiness and risk position. In short, relationships wherein cooperation is based on communication are more resilient to negative shocks than the ones wherein cooperation is based on economic incentives.

On the cognitive level, results indicate that both conditions have similar effects on cooperation levels after an adverse event. When the endowment reduction was introduced for one player of the pair, contributions in $\mathrm{G}$ account dropped for both conditions. In the communication condition, however, causal attribution was less likely to be internal than in the bonus condition. Moreover, counterpart's 
perceived responsibility for the negative outcomes were alleviated, as well as the perception that an opportunistic behavior would happen in the future. Consequently, perceived benevolence and perceived integrity were more resilient in relationships wherein cooperation was based on communication than in the ones that was based on economic incentives. Such positive causal attribution observed in the communication condition implies that injured parties were more likely to assume that the cause of the negative outcome was due to external reasons, and that the counterpart could not control it.

As for the behavioral effect, the two types of relationship are associated to different effects on the willingness to take risks after an alleged violation. In the communication condition, the trustor undertook a higher risk than the ones in the bonus condition. More important, the risk taken was positively related to the perceived trustworthiness of the other after the negative event. These findings support Tomlinson and Mryer (2009) propositions about the feedback looping between perceived trustworthiness and subsequent behavior. Therefore, perceptions of an eventual non-cooperative behavior of the other have considerable effect on the risk taken in future interactions.

Regarding to trustee's decisions in the investment game, the two types of relationship are not different with respect to decisions to reciprocate counterpart's trusting action. Trustee's decisions were related to the risk taken by the trustor. Results also show that the most frequent return strategy adopted by trustees was the give back. Moreover, zero returns strategy was rarely used (only $7 \%$ of total choices). Such findings are consistent with the idea that people tend to view themselves in a positively manner (Murnighan, Oesch, \& Pillutla, 2001) and, as such, may feel a moral obligation to return at least the amount sent, avoiding to be seen as selfish and greedy to their own eyes.

Moreover, more generous return strategies were observed, when trustors had sent their entire endowment. Thus, results support the assertion that taking small risks may send a message of lack of trust, reducing the likelihood of reciprocity. So, after a negative event, taking greater risks, despite engendering greater vulnerability, may be the most appropriate strategy to ensure higher levels of cooperation from the counterpart.

Overall, these results reinforce the need to take into account intrinsic motivation and relational features in organization design. Given that the history of a relationship has important effects on how members of an organization react to an alleged trust violation, studies in organizations should consider its inclusion in their analysis. In particular, our findings reinforce a more general criticism that one should be careful with the limits of managerial prescriptions based only on economic incentives.

\section{Managerial Implications}

This study suggests some practical implications related to the choice of mechanisms to foster cooperation.

First, the results suggest implications for the design of incentives in inter-firm contracts and within organizations. Economic incentives are normally seen as powerful mechanisms to restrain opportunistic behavior by means of legal sanctions for noncompliance, and explicit rewards for cooperation. Nevertheless, since they are grounded in explicit economic incentives for cooperation, they hinders one's ability of judging the other as benevolent or trustworthy (Malhotra \& Murnighan, 2002) and, hence, crowds out intrinsic incentives in a substitution effect (Frey \& Jegen, 2001). In contrast, our results suggest that motivational solutions (such as communication), which rely on intrinsic motivation (Poppo \& Zenger, 2002), are more resilient to negative events, since they engender more positive causal attributions and greater perceived trustworthiness in the aftermath of an alleged trust violation.

Second, after the occurrence of a negative event, partners may become more careful and take relatively small risks in order to lessen vulnerability to exploitation. However, this non-committal behavior may send a message of lack of trust and hamper reciprocity. In our findings, reciprocity was 
mainly influenced by the risk position taken. Therefore, sending a clear signal of trust (engaging in trusting action) helps to rebuild trust and to encourage further cooperation of the counterpart.

Summing up, we submit that motivational solutions are particularly important in transactions subjected to high uncertainty, in particular when the adverse shocks are only partially observed. This is the case of transactions within organizations that operate in different geographic locations, which is typically the case of tourism service networks and academic collaboration. Moreover, relational contracting is likely more efficient in countries where institutions are weaker and regulation unpredictable. For its resilience property, motivational solutions deal more efficiently with the adverse shocks that are more likely in riskier business environment.

The practical implications presented here derive from the results that established causal relations between the type of past relationship and trust violation outcomes. It is necessary to acknowledge that findings from lab experiments, although precise in terms of internal validity, may not be robust to be implemented in real business settings. For this reason, future research in real business settings would complement the findings presented here, what would increase the reliability of managerial prescriptions. This is the subject of next section.

\section{Limitations and Future Research}

Some limitations in the study need to be addressed. First, in the communication condition, faceto-face communication has occurred only once over the game. As a result, some may argue that it just has enabled coordination of decisions to maximize joint results rather than allow the emergence of social norms. However, other studies have already found that the mere visual identification of the partner was able to raise cooperation levels due to reducing social distance (Andreoni \& Petrie, 2004). Moreover, the absence of explicit incentives to enhance cooperation in the communication condition indicates that any cooperative action denotes the existence of some social norm improving cooperative behavior. Nevertheless, the absence of an instrument that could capture the content of communication between participants is, in fact, a limitation.

Second, other concern relates to the sample used. Participants were undergraduate students. Several other studies (see Davis \& Holt, 1993 for a revision) have already compared the behavior of decision makers in natural environments with those observed in standard sample used in experiments (undergraduate or MBA students) and no difference was detected. Besides, the decision problem presented to participants did not require any kind of specific knowledge or experience. Nevertheless, it would be worthwhile to replicate this study with a different population (i.e. middle and senior level managers).

Third, due to the size of the sample, only one player (the victim in the PGG) of each pair played as trustor in the investment game. Therefore, it was not possible to analyze risk taken by the player who played the offender role in the public good game and observe the use of some defense strategy by this player against any eventual retaliation from the counterpart, for example. So it would be useful to examine whether different roles played in the PGG may influence decisions in the investment game.

Finally, according to Dirks, Lewicki and Zaheer (2009), three important domains are affected by a trust violation: cognitive, behavioral and emotional. The first two were addressed in the current study. It would be interesting to examine the emotional response following a transgression, since negative emotions (such as anger, frustration and outrage) may entail severe implications for the viability of the relationship.

Despite these limitations, our findings offer some opportunities for future research. First, it may be worth testing empirically how prior relationship might affect trusting intentions and risk taking between partners in the aftermath of a trust violation. Moreover, one could test if companies more subject to external shocks would rely less intensively on economic incentives as a mechanism to foster 
cooperation. This vein of research based on real data would also add external validity to some findings of this paper. Such effort contributes to the current discussion of contracting and interfirm governance literature on how contracts are formed and how they should be designed to work effectively (Harmon et $a l ., 2015)$.

In addition, this study examines how prior relationship affects trust in exchange relationships after an alleged trust violation, i.e. a negative occurrence in the relationship whose cause could not be observed. As a result, we did not specify what was the type of trust violation committed. However, trust violations might be attributed to matters of competence or integrity and past studies have already shown that these attributions matters might influence the effectiveness of trust repair (Kim et al., 2013; Kim et $a l ., 2006)$. Future research should investigate the relationship between type of violation and history of cooperation (based on explicit or implicit incentives) and its implications for trust repair within exchange relationships.

\section{Note}

${ }^{1}$ The questionnaire in Portuguese is presented in the Appendix.

\section{References}

Agarwal, R., Croson, R., \& Mahoney, J. (2010). The role of incentives and communication in strategic aliances: an experimental investigation. Strategic Management Journal, 31(4), 413-437. http://dx.doi.org/10.1002/smj.818

Andreoni, J., \& Petrie, R. (2004). Public good experiments without confidentiality: a glimpse into fundraising. Journal of Public Economics, 88(7/8), 1605-1623. http://dx.doi.org/10.1016/S00472727(03)00040-9

Axelrod, R. (1984). The evolution of cooperation. New York, NY: Basic Books.

Balliet, D. (2010). Communication and cooperation in social dilemmas: a meta-analytic review. The Journal of Conflict Resolution, 54(1), 39-57. http://dx.doi.org/10.1177/0022002709352443

Balliet, D., Mulder, L. B., \& Van Lange, P. A. M. (2011). Reward, punishment, and cooperation: a metaanalysis. Psychological Bulletin, 137(4), 594-615. http://dx.doi.org/10.1037/a0023489

Balliet, D., Parks, C. D., \& Joireman, J. (2009). Social value orientation and cooperation: a metaanalysis. Group Processes and Integroup Relations, 12(4), 533-547. http://dx.doi.org/10.1177/1368430209105040

Balliet, D., \& Van Lange, P. A. M. (2013). Trust, punishment, and cooperation across 18 societies: a meta-analysis. Perspectives on Psychological Science, 8(4), 363-379. http://dx.doi.org/10.1177/1745691613488533

Barclay, P., \& Kiyonari, T. (2014). Why sanction? Functional causes of punishment and reward. In P. A. M. Van Lange, B. Rockenbach, \& T. Yamagishi (Eds.), Reward and punishment in social dilemmas (pp. 182-196). New York: Oxford University Press.

Berg, J., Dickhaut, J., \& McCabe, K. (1995). Trust, reciprocity, and social history. Games and Economic Behavior, 10(1), 122-142. http://dx.doi.org/10.1006/game.1995.1027 
Bies, R. J., \& Tripp, T. M. (1996). Beyond distrust: getting even and the need for revenge. In R. M. Kramer \& T. Tyler (Eds.), Trust in organizations: frontiers of theory and research (pp. 246-260). Thousand Oaks, CA: Sage.

Bogaert, S., Boone, C., \& Declerck, C. (2008). Social value orientation and cooperation in social dilemmas: a review and conceptual model. British Journal of Social Psychology, 47(3), 453-480. http://dx.doi.org/10.1348/014466607X244970

Boone, C., Declerck, C., \& Kiyonari, T. (2010). Inducing cooperative behavior among proselfs versus prosocials: the moderating role of incentives and trust. Journal of Conflict Resolution, 54(5), 799824. http://dx.doi.org/10.1177/0022002710372329

Bottom, W., Gibson, K. S., Daniels, S., \& Murnighan, J. K. (2002). When talk is no cheap: substantive penance and expressions of intent in rebuilding cooperation. Organization Science, 13(5), 497513. http://dx.doi.org/10.1287/orsc.13.5.497.7816

Cohen, T. R., Wildschut, T., \& Insko, C. A. (2010). How communication increases interpersonal cooperation in mixed motive situations. Journal of Experimental Social Psychology, 46(1), 3950. http://dx.doi.org/10.1016/j.jesp.2009.09.009

Cook, K. S., Yamagishi, T., Cheshire, C., Cooper, R., Matsuda, M., \& Mashima, R. (2005). Trust building via risk taking: a cross-societal experiment. Social Psychology Quarterly, 68(2), 121142. http://dx.doi.org/10.1177/019027250506800202

Davis, D. D., \& Holt, C. A. (1993). Experimental economics. New Jersey: Princeton University Press.

Dirks, K. T., \& Ferrin, D. L. (2001). The role of trust in organizational settings. Organization Science, 12(4), 450-467. http://dx.doi.org/10.1287/orsc.12.4.450.10640

Dirks, K. T., Lewicki, R. J., \& Zaheer, A. (2009). Repairing relationships within and between organizations: building a conceptual foundation. Academy of Management Review, 34(1), 68-84. http://dx.doi.org/10.5465/AMR.2009.35713285

Elangovan, A. R., Auer-Rizzi, W., \& Szabo, E. (2007). Why don't I trust you know? An attributional approach to erosion of trust. Journal of Managerial Psychology, 22(1), 4-24. http://dx.doi.org/10.1108/02683940710721910

Elangovan A. R., \& Shapiro, D. (1998). Betrayal of trust in organizations. Academy of Management Review, 23(3), 547-566. http://dx.doi.org/10.5465/AMR.1998.926626

Falk, A., Gatcher, S., \& Kovacs, J. (1999). Intrinsic motivation and extrinsic incentives in a repetead game with incomplete contracts. Journal of Economic Psychology, 20(3), 251-284. http://dx.doi.org/10.1016/S0167-4870(99)00009-4

Falk, A., \& Kosfeld, M. (2006). The hidden costs of control. American Economic Review, 96(5), 16111630. http://dx.doi.org/10.1257/aer.96.5.1611

Fehr, E. (2009). On the economics and biology of trust. Journal of the European Economic Association, 7(2/3), 235-266. http://dx.doi.org/10.1162/JEEA.2009.7.2-3.235

Fehr, E., \& Gatcher, S. (2002). Altruistic punishments in humans. Nature, 415, 137-140. http://dx.doi.org/10.1038/415137a

Fehr, E., \& Schmidt, K. M. (2007, January). Adding a stick to the carrot? The interaction of bonuses and fines. Proceedings of American Economic Association Annual Meeting, Chicago, IL, USA, 57. Retrieved from https://www.aeaweb.org/annual_mtg_papers/2007/0105_1015_1701.pdf 
Fischbacher, U. (2007). Z-tree: Zurich toolbox for ready-made economic experiments. Experimental Economics, 10(2), 171-178. http://dx.doi.org/10.1007/s10683-006-9159-4

Frey, B. S., \& Jegen, R. (2001). Motivation crowding theory. Journal of Economic Surveys, 15(5), 589611. http://dx.doi.org/10.1111/1467-6419.00150

Harmon, D. J., Kim, P. H., \& Mayer, K. J. (2015). Breaking the letter vs. spirit of the law: how the interpretation of contract violations affects trust and the management of relationships. Strategic Management Journal, 36(4), 497-517. http://dx.doi.org/10.1002/smj.2231

Heider, F. (1958). The psychology of interpersonal relations. New York: Wiley.

Jackson, J. W. (2011). Intragroup cooperation as a function of group performance and group identity. Group Dynamics: Theory, Research, and Practice, 15(4), 343-356. http://dx.doi.org/10.1037/a0024575. 343

Kim, P. H., Cooper, C. D., Dirks, K. T., \& Ferrin, D. L. (2013). Repairing trust with individuals vs. groups. Organizational Behavior and Human Decision Processes, 120(1), 1-14. http://dx.doi.org/10.1016/j.obhdp.2012.08.004

Kim, P. H, Dirks, K. T., Cooper, C. D., \& Ferrin, D. L. (2006). When more blame is better than less: the implications of internal vs external attributions for the repair of trust after a competence vs integrity-based trust violation. Organization Behavior and Human Decision Processes, 99(1), 4965. http://dx.doi.org/10.1016/j.obhdp.2005.07.002

Kim. P. H, Ferrin, D. L., Cooper, C. D., \& Dirks, K.T. (2004). Removing the shadow of suspicion: the effects of apology versus denial for repairing competence versus integrity-based trust violations. Journal of Applied Psychology, 89(1), 104-118. http://dx.doi.org/10.1037/0021-9010.89.1.104

Kollock, P. (1998). Social dilemmas: the anatomy of cooperation. Annual Review of Sociology, 24, 183214. http://dx.doi.org/10.1146/annurev.soc.24.1.183

Komorita, S. S., \& Parks, C. D. (1994). Social dilemmas. Madison, WI: Brown \& Benchmark.

Kramer, R. M. (1999). Trust and distrust in organizations: emerging perspectives, enduring questions. Annual Review of Psychology, 50, 569-598. http://dx.doi.org/10.1146/annurev.psych.50.1.569

Kramer, R. M., \& Lewicki, R. J. (2010). Repairing and enhancing trust: approaches to reducing organizational trust deficits. Academy of Management Annals, 4(1), 245-277. http://dx.doi.org/10.1080/19416520.2010.487403

Lazzarini S. G., Miller, G. J., \& Zenger, T. R. (2004). Order with some law: complementarity versus substitution of formal and informal agreements. Journal of Law, Economics, \& Organization, 20(2), 261-298. http://dx.doi.org/10.1093/jleo/ewh034

Ledyard, J. O. (1995). Public goods: a survey of experimental research. In J. H. Kagel \& A. E Roth (Eds.), The handbook of experimental economics (pp. 111-195). New Jersey: Princeton University Press.

Lewicki, R. J., \& Bunker, B. B. (1996). Developing and maintaining trust in working relationships. In R. M. Kramer \& T. Tyler (Eds.), Trust in organizations: frontiers of theory and research (pp. 114-139). Thousand Oaks, CA: Sage.

Lount, R. B., Jr., Zhong, C., Sivanathan, N., \& Murnighan, J. K. (2008). Getting off on the wrong foot: the timing of a breach and the restoration of trust. Personality and Social Psychology Bulletin, 34(12), 1601-1612. http://dx.doi.org/10.1177/0146167208324512 
Malhotra, D., \& Murnighan, J. K. (2002). The effects of contracts on interpersonal trust. Administrative Science Quarterly, 47(3), 534-559. http://dx.doi.org/10.2307/3094850

Mayer, R. C., \& Davis, J. H. (1999). The effect of the performance appraisal system on trust for management: a field quasi-experiment. Journal of Applied Psychology, 84(1), 123-136. http://dx.doi.org/10.1037/0021-9010.84.1.123

Mayer, R. C., Davis, J. H., \& Schoorman, F. D. (1995). An integrative model of organizational trust. $\begin{array}{llll}\text { Academy of } & \text { Management 20(3), } & \text { 709-734. }\end{array}$ http://dx.doi.org/10.5465/AMR.1995.9508080335

McKnight, D. H., Cummings, L. L., \& Chervany, N. L. (1998). Initial trust formation in new organizational relationships. Academy of Management Review, 23(3), 473-490. http://dx.doi.org/10.5465/AMR.1998.926622

Meleady, R., Hopthrow, T., \& Crisp, R. J. (2013). The group discussion effect: integrative processes and suggestions for implementation. Personality and Social Psychology Review, 17(1), 56-71. http://dx.doi.org/10.1177/1088868312456744

Mellewigt, T., Madhok, A., \& Weibel, A. (2007). Trust and formal contracts in interorganizational relationships: substitutes and complements. Managerial and Decisions Economics, 28(8), 833847. http://dx.doi.org/10.1002/mde.1321

Messick, D. M., \& Brewer, M. B. (1983). Solving social dilemmas. In L. Wheeler \& P. Shaver (Eds.), Review of personality and social psychology (Vol. 4, pp. 11-44). Beverly Hills: CA Sage.

Morrison, E. W., \& Robinson, S. L. (1997). When employees feel betrayed: a model of how psychological contract violation develops. Academy of Management Review, 22(1), 555-572. http://dx.doi.org/10.5465/AMR.1997.9707180265

Murnighan, J. K., Oesch, J. M., \& Pillutla, M. (2001). Player types and self-impression management in dictator games: two experiments. Games and Economic Behavior, 37(2), 388-414. http://dx.doi.org/10.1006/game.2001.0847

Nosenzo, D., \& Sefton, M. (2013). Promoting cooperation: the distribution of reward and punishment power. In P. A. M. Van Lange, B. Rockenbach, \& T. Yamagishi (Eds.), Social dilemmas: new perspectives on reward and punishment (pp. 87-114). New York: Oxford University Press.

Orbell, J. M., Van de Kragt, A. J., \& Dawes, R. M. (1988). Explaining discussion-induced cooperation. Journal of Personality and Social Psychology, 54(5), 811-819. http://dx.doi.org/10.1037/00223514.54.5.811

Ostrom, E., Walker, J., \& Gardner, R. (1992). Covenants with or without a sword: self-governance is possible. The American Political Science Review, 86(2), 404-417. http://dx.doi.org/10.2307/1964229

Pillutla, M. M., Malhotra, D., \& Murnighan, J. K. (2003). Attributions of trust and the calculus of reciprocity. Journal of Experimental Social Psychology, 39(5), 448-455. http://dx.doi.org/10.1016/S0022-1031(03)00015-5

Poppo, L., \& Zenger, T. (2002). Do formal contracts and relational governance function as substitutes or complements? Strategic Management Journal, 23(8), 707-725. http://dx.doi.org/10.1002/smj.249

Rousseau, D. M., Sitkin, S. B., Burt, R. S., \& Camerer, C. (1998). Not so different after all: a crossdiscipline view of trust. Academy of Management Review, 23(3), 393-404. http://dx.doi.org/10.5465/AMR.1998.926617 
Sally, D. (1995). Conversation and cooperation in social dilemmas: a meta-analysis of experiments from 1958 to 1992. Rationality and Society, 7(1), 58-92. http://dx.doi.org/10.1177/1043463195007001004

Shapiro, D. L. (1991). The effects of explanations on negative reactions to deceit. Administrative Science Quarterly, 36(4), 614-630. http://dx.doi.org/10.2307/2393276

Tazelaar, M. J. A., Van Lange, P. A. M., \& Ouwerkerk, J. W. (2004). How to cope with "noise" in social dilemmas: the benefits of communication. Journal of Personality and Social Psychology, 87(6), 845-859. http://dx.doi.org/10.1037/0022-3514.87.6.845

Tenbrunsel, A. E., \& Messick, D. M. (1999). Sanctioning systems, decision frames, and cooperation. Administrative Science Quarterly, 44(4), 684-707. http://dx.doi.org/10.2307/2667052

Tomlinson, E. C., Dineen, B. R., \& Lewicki, R. J. (2004). The road to reconciliation: antecedents of victim willingness to reconcile following a broken promise. Journal of Management, 30(2), 165187. http://dx.doi.org /10.1016/j.jm.2003.01.003

Tomlinson, E. C., \& Mryer, R. C. (2009). The role of causal attribution dimensions in trust repair. Academy of Management Review, 34(1), 85-104. http://dx.doi.org/10.5465/AMR.2009.35713291

Van Lange, P. A. M., Balliet, D., Parks, C., \& Van Vugt, M. (2013). Social dilemmas: understanding the psychology of human cooperation. New York: Oxford University Press.

Van Lange, P. A. M., Joireman, J., Craig, D. P., \& Djik, E. V. (2013). The psychology of social dilemmas: a review. Organizational Behavior and Human Decision Processes, 120(2), 125-141. http://dx.doi.org/10.1016/j.obhdp.2012.11.003

Weber, J. M., Kopelman, S., \& Messick, D. M. (2004). A conceptual review of decision making in social dilemmas: applying a logic of appropriateness. Personality and Social Psychology Review, 8(3), 281-307. http://dx.doi.org/10.1207/s15327957pspr0803_4

Weber, J. M., \& Murnighan, J. K. (2008). Suckers or saviors? Consistent contributors in social dilemmas. Journal of Personality and Social Psychology, 95(6), 1340-1353. http://dx.doi.org/10.1037/a0012454

Weiner, B. (1986). An attributional model of motivation and emotion. New York: Springer-Verlag.

Weiner, B. (2012). An attribution theory of motivation. In P. A. M. Van Lange, A. W. Kruglanski, \& E. T. Higgins (Eds.), Handbook theories of social psychology (pp. 135-255). Thousand Oaks, CA: Sage.

Woolthuis, R. K., Hillebrand, B., \& Nooteboom, B. (2005). Trust, contract, and relationship $\begin{array}{llll}\text { development. } & \text { Organization } & \text { Studies, } & \text { 26(6), }\end{array}$ http://dx.doi.org/10.1177/0170840605054594

Zeng, M., \& Chen, X.-P. (2003). Achieving cooperation in multiparty alliances: a social dilemma approach to partnership management. Academy of Management Review, 28(4), 587-605. http://dx.doi.org/10.5465/AMR.2003.10899383 


\section{Authors' Profiles}

Tatiana Iwai

Rua Quatá, 300, Vila Olímpia, 04546-042, São Paulo, SP, Brazil. E-mail address: tatianai@insper.edu.br

Paulo Furquim de Azevedo

Rua Quatá, 300, Vila Olímpia, 04546-042, São Paulo, SP, Brazil. E-mail address: PauloFA1 @insper.edu.br 


\section{APPENDIX}

A partir das decisões tomadas pelo seu parceiro no jogo, para cada afirmação, aponte o número que melhor descreve o quanto você concorda ou discorda de cada afirmação, usando a seguinte escala:

\begin{tabular}{ccccc}
\hline $\begin{array}{c}\text { Discordo } \\
\text { fortemente }\end{array}$ & Discordo & $\begin{array}{c}\text { Nem concordo nem } \\
\text { discordo }\end{array}$ & Concordo & $\begin{array}{c}\text { Concordo } \\
\text { fortemente }\end{array}$ \\
\hline 1 & 2 & 3 & 4 & 5 \\
\hline
\end{tabular}

"Meu parceiro se preocupou com meu bem-estar."

"Minhas necessidades e desejos foram muito importantes para guiar as decisões do meu parceiro."

"Meu parceiro realmente levou em consideração o que era importante para mim."

"Meu parceiro fez esforço para me ajudar."

"Meu parceiro apresentou um forte senso de justiça."

"Eu não tenho dúvidas que meu parceiro cumpriu sua palavra."

"Meu parceiro tentou fortemente ser justo nas interações comigo."

"As ações e comportamentos do meu parceiro não foram muito consistentes."

"Bons princípios parecem ter guiado o comportamento do meu parceiro."

Com quantas moedas você percebe que seria justo que seu parceiro tivesse contribuído a cada rodada na conta $\mathrm{D}$ ? (De 0 a 20 moedas) moedas.

Nas rodadas anteriores do jogo, caso tenha ocorrido algum evento que NÃO tenha atendido às suas expectativas de cooperação, responda as questões abaixo, usando a escala a seguir. CASO O EVENTO TENHA ATENDIDO COMPLETAMENTE ÀS SUAS EXPECTATIVAS, PULE AS PRÓXIMAS TRÊS QUESTÕES.

"Meu parceiro pode ser considerado o culpado pelo resultado negativo no jogo, por não ter contribuído na conta D com a quantia de moedas que eu esperava."

"Meu parceiro poderia ter feito algo para evitar ou minimizar o resultado negativo no jogo."

"Posso esperar que meu parceiro se comporte de maneira inadequada em eventos futuros."

A partir das decisões tomadas por seu parceiro nas rodadas anteriores do jogo, aponte o número que melhor descreve o quanto você acredita ser improvável ou provável cada afirmação abaixo, usando a seguinte escala:

\begin{tabular}{ccccccc}
\hline Muito improvável & & \multicolumn{2}{c}{ Nem improvável nem provável } & Muito provável \\
\hline 1 & 2 & 3 & 4 & 5 & 6 & 7 \\
\hline
\end{tabular}


"Qual a probabilidade de você manter seu parceiro atual no jogo, caso você tenha a possibilidade de trocá-lo por um novo parceiro desconhecido?"

"Você estaria disposto a deixar seu atual parceiro se reconciliar com você, dadas as ações dele durante o jogo?"

"Qual é a probabilidade de você confiar novamente no seu atual parceiro, do mesmo modo em que confiou no início do jogo?"

Assinale a opção abaixo que melhor expressa seu grau de amizade prévio com o indivíduo que foi alocado como seu parceiro no jogo:

( ) Não conhecia esta pessoa previamente.

( ) Conheço de vista esta pessoa.

( ) Já conversei algumas vezes com esta pessoa, mas não posso dizer que a conheço bem.

( ) Conheço bem esta pessoa porque converso bastante com ela.

( ) Conheço bem esta pessoa porque sou grande amigo dela. 